\title{
IDENTIFIKASI RAYAP BENUANG BINI (Octomeles sumatrana Miq) DI KHDTK HAURBENTES
}

\author{
Yeni Nuraeni ${ }^{1}$, Illa Anggraeni ${ }^{2}$, Rina Bogidarmanti ${ }^{3}$ \\ ${ }^{1,2,3}$ Pusat Penelitian dan Pengembangan Hutan \\ Kampus Balitbang Kehutanan, Jl. Gunung Batu No. 5 Kotak Pos 165, Bogor 16118 \\ Telp. (0251) 8633234, 7520067 Fax. (0251) 8638111 \\ Korespondesi Email: y.nuraeni999@gmail.com
}

Diterima : 7 Agustus 2016

Disetujui : 8 November 2016

\section{Intisari}

Tanaman Benuang Bini merupakan salah satu tanaman alternatif bahan baku industri pulp. Jenis ini belum dikembangkan secara luas dalam hutan tanaman. Kegiatan pengembangan dalam bentuk demplot telah dikembangkan oleh Badan Litbang Kehutanan di KHDTK Haurbentes Jawa Barat. Dalam pengembangannya terjadi serangan hama. Hama rayap. Penelitian dilakukan pada bulan Oktober 2014, bertujuan untuk mengidenti $\square$ kasi jenis rayap yang menyerang, mengetahui persentase serangan dan pengamatan terhadap gejala serangan rayap. Penelitian menggunakan metode survey, pengambilan contoh rayap dan identi $\square$ kasi jenis rayap di laboratorium. Hasil identi $\square$ kasi rayap yang menyerang adalah rayap Microtermes sp., famili Termitidae. Persentase serangan relatif rendah yaitu sebesar $0,8 \%$. Pengendalian rayap dilakukan dengan cara eradikasi dan pemusnahan rayap dari areal pertanaman.

Kata Kunci: Benuang Bini, Hama, Microtermes sp., Termitidae

\begin{abstract}
Benuang Bini Plant is one of alternative plant as raw material for the pulp industry. This species hasn't been develoved extensively in the form forest plantation in Indonesia. Development activities in the form of pilot project has been developed by the Forestry Reseach and Development in KHDTK Haurbentes, West Java. In the benuang bini plant development, have various constraints such as pest and diseases attack. One of the pest that attack benuang bini plant in KHDTK Haurbentes is termite. The study was conducted in October 2014 in KHDTK Haurbentes, aims to identify the species of termites, knowing the percentage and observation of symptoms of termite attack. The study was conducted by survey method, sampling termites and termite species identi $\square$ cation in the laboratory. The identi $\square$ cation result termites that attack benuang bini is Microtermes sp. famili Termitidae. The percentage of attack are relatively low at 0,8\%. Termite control done by eradication and extermination from planting area.
\end{abstract}

Keyword: Microtermes sp, Pest, Termitidae

\section{PENDAHULUAN}

Binuang Bini (Octomeles sumatrana Miq.) termasuk dalam famili Datiscaceae, dan berpotensi sebagai bahan baku pulp. Di Indonesia memiliki beberapa nama daerah yakni Binuang, Benuwang, Binuang laki (Sumatera)
Benuang Bini, Benuang, Bunuang, Bunuang Bini (Kalimantan), Winuang, Wenuang, Benua Motutu (Sulawesi), Palaka, Senao, Tina, Kapu, Walada (Maluku), Buwar, Kijare, Jare, Senao, Tina (Papua). Daerah penyebaran di Aceh, Sumatera Barat, Sumatera Selatan, Sulawesi, Maluku dan Papua (Martawijaya et al, 1989). 
Habitus Binuang Bini berbentuk pohon dengan ukuran sedang hingga tinggi mencapai $45 \mathrm{~m}$ atau lebih dengan tinggi bebas cabang 30 m. Diameter 250 - 400 cm. Banir dijumpai pada ketinggian sekitar $6 \mathrm{~m}$. Jenis binuang Bini mengalami musim pembungaan dan pembuahan hampir sepanjang tahun dan buah akan berbuah pada bulan Mei, Juli, September dan Desember (Martawidjaya et al, 1989). Tempat tumbuh Binuang Bini umumnya dijumpai pada tanah kering atau tanah lembab di pinggiran sungai dengan tekstur tanah liat, atau liat berpasir, pada ketinggian hingga $1000 \mathrm{~m}$ dpl. Tipe iklim yang dikehendaki adalah iklim basah hingga agak kering dengan tipe curah hujan A-C (Martawijaya et al, 1989).

Kayu Binuang Bini dapat digunakan untuk pembuatan chipboard, veneer, moulding $\square$ breboard, kayu lapis, pulp, peti kemas, kotak korek api, perahu dan sampan (Martawidjaya et al, 2005). Sebagai bahan baku pulp kayu Binuang Bini memiliki berat jenis 0,16-0,48, kadar selulosa 49,1 $\%$, lignin 23,2 \% dan panjang serat $1,427 \mathrm{U}$ (Martawidjaya et al, 1989; Aprianis dan Rahmayanti, 2009).

Di Indonesia belum dikembangkan pada hutan tanaman, baru dijumpai di Bali pada kegiatan pengembangan demplot oleh Badan Litbang Kehutanan di daerah KHDTK Haurbentes Jasinga Bogor dan Gunung Kidul, Yogyakarta. Permasalahan yang dihadapi dalam pengembangan tanaman dengan sistem monokultur adalah serangan hama dan penyakit. Pada demplot di lokasi KHDTK Haurbentes, pada tanaman berumur 2 (dua) tahun dijumpai serangan hama rayap. Persentase serangan relatif rendah sekitar $0,8 \%$, namun mengakibatkan tanaman tumbang dan mati. Hal ini karena rayap menyerang empulur tanaman sehingga batang menjadi rapuh. Guna mengantisipasi adanya serangan hama rayap yang lebih luas, maka perlu dilakukan kegiatan eksplorasi dan identi $\square$ kasi sehingga dapat diperoleh dasar untuk teknik pencegahan dan pengendalian yang tepat.

\section{METODE PENELITIAN}

Bahan yang digunakan adalah Benuang Bini. Alat yang digunakan adalah kotak serangga, kamera, mikroskopdanalattulis.Penelitiandilaksanakanpada bulan Oktober 2014 di KHDTK Haurbentes. Metode penelitian menggunakan metode survey pada 1500 plot tanaman Benuang Bini. Parameter yang diamati adalah jenis rayap yang menyerang, gejala serangan dan persentase serangan. Pengambilan sampel rayap diperoleh dengan mengambil gundukan sarang dan batang tanaman Benuang Bini yang telah roboh. Identi $\square$ kasi dilakukan dengan pengamatan gejala serangan di lapangan dan pengamatan morfologi rayap di laboratorium.

Persentase serangan rayap dihitung dengan menggunakan rumus:

$\mathbf{P}=\frac{\text { Jumlah tanaman yang terserang dalam plot pengamatan }}{\text { jumlah seluruh tanaman dalam plot pengamatan }}$

\section{HASIL DAN PEMBAHASAN}

Berdasarkan hasil identi $\square$ kasi di laboratorium, jenis hama yang menyerang tanaman Benuang Bini di KHDTK Haurbentes Jawa Barat adalah rayap tanah Microtermes sp. Gejala serangan terlihat penampakan alur-alur yang khas serta terdapat penumpukan tanah pada permukaan batang, persentase serangan rayap sebesar $0,8 \%$ tergolong kriteria rendah.

Rayap termasuk ordo Ispotera, famili termitidae. Merupakan kelompok rayap dengan populasi yang tinggi, memakan kayu (Xylophagus) terutama bahan yang mengandung selulosa (Nandika, dkk 2003). Rayap merupakan serangga sosial yang berukuran kecil sampai sedang, hidup berkoloni dan terbagi menjadi kasta-kasta khusus dalam kegiatan utamanya. Kasta reproduksi adalah sepasang individu betina (ratu atau gendon) dan jantan (raja), kasta reproduksi ini melaksanakan fungsi seksual dan reproduksi. Dua kasta lainnya yaitu kasta pekerja dan prajurit mandul. Pekerja berfungsi sebagai pencari makan (Forager casste) sedangkan prajurit sebagai komponen pertahanan koloni. Satu koloni 
dapat mencapai tujuh juta ekor, yang sebagian besar terdiri dari rayap pekerja. Koloni yang kecil dikendalikan oleh sepasang kasta reproduksi, dan kasta yang besar dihuni oleh beberapa pasang kasta reproduksi. Prajurit dan pekerja dapat dibedakan dari bentuk dan struktur kepalanya (Kasta prajurit tidak dikenal pada rayap-rayap golongan Apicotermitinae). Kepala dan mendibel prajurit lebih besar ukurannya dibandingkan kepala dan mendibel pekerja, Kepala prajurit sangat bervariasi bentuknya, digunakan untuk mengenali jenis-jenis rayap (Susilo, 2007)

Di seluruh dunia jenis-jenis rayap yang telah dikenal (dideskripsikan dan diberi nama) \pm 2.000 spesies (sekitar 120 spesies merupakan hama), sedangkan di Indonesia tercatat \pm 200 spesies, dan 20 spesies diantaranya telah diketahui berperan sebagai hama perusak kayu maupun hama hutan/pertanian (Waryono, 2004). Rayap yang menyerang tanaman Benuang Bini di KHDTK Haurbentes yaitu Microtermes sp. termasuk dalam golongan rayap tanah. Rayap tanah bersaraneg dalam tanah terutama dekat pada bahan organik yang mengandung selulosa seperti kayu, serasah dan humus. Contoh-contoh Termitidae yang paling umum adalam Macrotermes spp. Odontermes spp. dan Microtermes spp. Serangan rayap sangat ganas, dapat menyerang objek sejauh 200 meter dari sarangnya. Untuk mencapai kayu sasarannya, ini bahkan mampu menembus tembok dengan bantuan enzim yang dikeluarkan (Waryono, 2004). Famili Termitidae merupakan spesies rayap tingkat tinggi, dimana mayoritas anggota dibedakan berdasarkan jenis makanannya tergolong rayap grup II yaitu anggota rayap yang memakan kayu, rumput dan lumut (Haneda dan Firmansyah, 2012). Termitidae memiliki ciri yang tidak dimiliki oleh rayap lain yaitu memiliki mandibula yang asimetrikal, saling menyilang, membengkok dimana bentuk kepala yang memanjang (Elongated). Rayap termitidae membuat sarang dari tanah dan sisa kayu mati diatas permukaan tanah dan serasah. Sarang dibangun tidak jauh dari pohon atau menempel pada bagian bawah batang pohon (Handru et al, 2012).
Rayap Microtermes sp. memiliki kepala berwarna kuning muda, dengan rata-rata panjang mendibel 1,1 mm, lebar kepala 1,2 mm. (Sayuthi, 2012). Mendibel prajurit halus, panjang dan berbentuk arit, prajurit terdapat beberapa ukuran (polimorphic). Jenis ini berukuran kecil, prajurit dan pekerja dimor $\square$ s. Panjang prajurit besar 3,54,75 $\mathrm{mm}$ dan prajurit kecil 2,5-3,75 $\mathrm{mm}$. Terdapat 15 ruas antena prajurit, dengan panjang ruas antena untuk prajurit makro 4,0-4,5 mm dan prajurit mikro 3,3- 3,8 mm (Gambar 1) (Tarumingkeng, 1971).
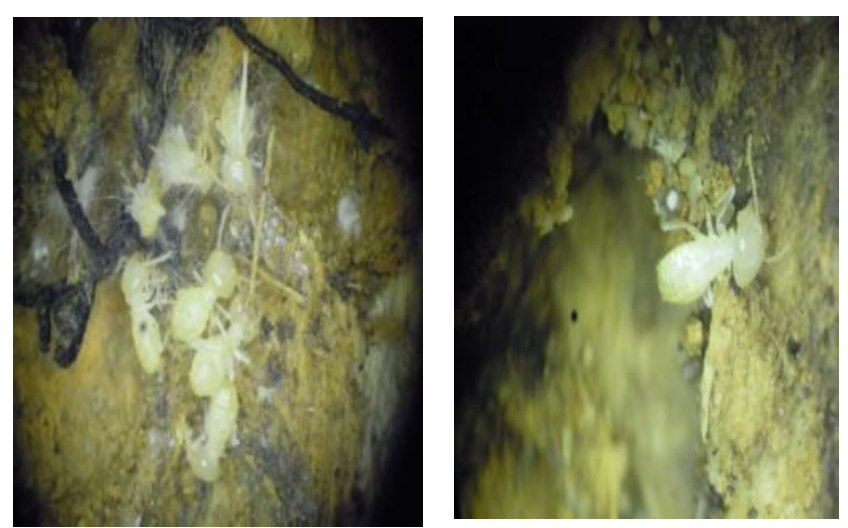

Gambar 1. Rayap Yang Menyerang Tanaman Benuang Bini

Gejala serangan rayap dikenali karena terdapat penumpukan tanah pada permukaan batang dengan alur-alur dari tanah. Lapisan tanah dimulai dari pangkal batang yang berbatasan dengan tanah hingga ketinggian 10 meter, yang apabila dilakukan pembongkaran terhadap tanaman maka akan terlihat bahwa serangan dimulai dari akar, kemudian ke pangkal batang dan terus naik sampai ke atas (Gambar 2).

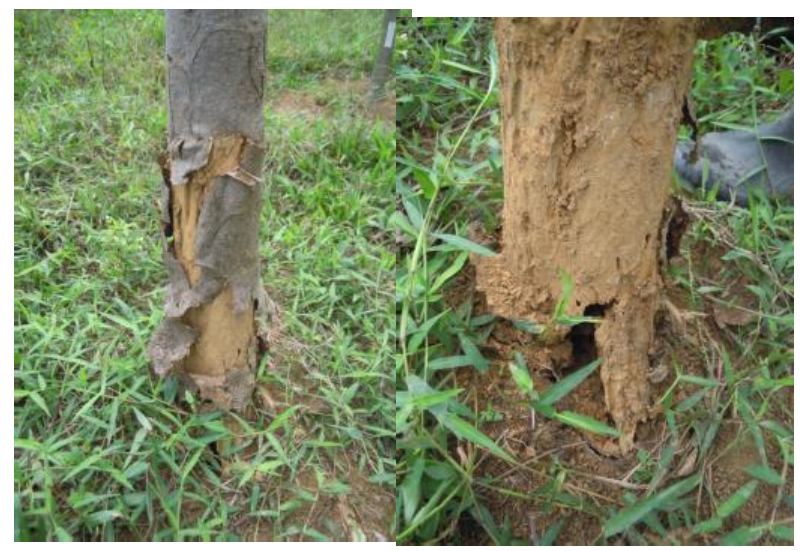

Gambar 2. Gejala Serangan Rayap Pada Tanah 
Lapisan-lapisan tanah pada permukaan batang merupakan saluran-saluran penghubung dengan sarangnya yang berada dalam tanah. Di dalam tanah terdapat rayap prajurit dan rayap pekerja. Penggerekan batang dilakukan oleh rayap pekerja, dimana batang tanaman bagian dalam menjadi lapuk dan hancur akibat gerekan rayap, tajuk tanaman menjadi kering, tanaman mudah roboh dan pada serangan yang berat menyebabkan kematian (Kehek et al, 2007).

Persentase serangan rayap di KHDTK Haurbentes masih rendah yaitu $0,8 \%$, dari jumlah 1500 pohon yang ditanam, hanya 12 pohon yang terserang. Walaupun persentase serangannya masih rendah, serangan rayap perlu diwaspadai karena seragannya sangat cepat dari pohon ke pohon. Apabila kondisi lingkungan mendukung maka serangan rayap dapat meningkat sehingga dapat mempengaruhi produksi Benuang Bini

Pengendalian terhadap serangan rayap melalui eradikasi dan pemusnahan dari areal pertanaman apabila serangan rayap mulai ditemukan sehingga rayap tidak sempat berkembang dan meluas (Asmaliyah et al, 2011).

\section{KESIMPULAN}

Jenis rayap yang menyerang tanaman Benuang Bini (Octomeles sumatrana) di KHDTK Haurbentes adalah jenis Microtermes sp. famili Termitidae. Microtermes sp. termasuk dalam kelompok rayap tanah, dengan gejala serangan yang sangat khas yaitu terdapat penumbukan tanah pada batang tanaman yang terserang. Persentase serangannya masih sangat rendah yaitu hanya sebesar $0,8 \%$, akan tetapi perlu diwaspadai karena serangan rayap dari pohon ke pohon sangat cepat.

\section{DAFTAR PUSTAKA}

Aprianis, Y dan Rahmayanti, S 2009, Dimensi Serat dan Nilai Turunannya dari 7 Jenis Kayu Asal Provinsi Jambi, Jurnal Penelitian Hasil Hutan, 27 (1).
Asmaliyah, A Imanullah \& Darwiati, W 2011, Identi $\square$ kasi dan Potensi Kerusakan Rayap pada Tanaman Tembesu (Fagraea fragrans) di Kebun Percobaan Way Hanakau, Lampung Utara, Jurnal Penelitian Hutan Tanaman, 9 (4): 187-194.

Handru, A, Herwina, H \& Dahelmi 2012, JenisJenis Rayap (isoptera) di Kawasan Hutan Bukit Tengah Pulau dan Areal Perkebunan Kelapa Sawit, Solok Selatan. Jurnal Biologi Universitas Andalas, 1(1): 111-119.

Haneda, NF \& Firmansyah,A2012, Keanekaragaman Rayap Tanah di Hutan Pendidikan Gunung Walat, Sukabumi, Jurnal Silvikultur Tropika, 03 (02): 92-96.

Kehek, A, Anggraeni, I \& Suripatti, BA 2007, Identi $\square$ kasi Rayap yang Menyerang Araucaria cuninghamii di Kebun Konservasi Wanariset Inamberi, Manokwari, Papua, Info Hutan Tanaman 2(1): 39-46.

Martawidjaya, A, Kartasudjana, I, Mandang, YI, Prawira, SA \& Kadir, K 2005. Atlas kayu indonesia. Jilid II. Departemen Kehutanan. Badan Penelitian Dan pengembangan Kehutanan. Bogor, Indonesia.

Mindawati, N 2007, Jenis-jenis alternatif sebagai bahan baku kayu pulp. 2007. Mitra Hutan Tanaman, 2 (1).

Nandika, D, Rismayadi, Y \& Diba, F 2003. Rayap: biologi dan pengendaliannya. Muhammadiyah University Press, Surakarta.

Sayuthi, M 2012. Identi $\square$ kasi spesies rayap perusak tanaman jarak pagar (Jatropha curcas L.). Jurnal Ilmiah Pendidikan Biologi 4(2): 118 -

121.

Susilo, FX 2007, Keanekaragaman serangga indonesia, posisinya di dunia dan perubahan tata guna lahan: kasus rayap, Dipresentasikan pada Konferensi Nasional Konservasi Serangga, Konservasi Serangga Pada Bentang Alam: Peluang dan Tantangan, diakses pada tanggal 4 Juni 2015, (www.staff.unila.ac.id).

Tarumingkeng, R.C. 1971. Biologi dan pengendalian rayap perusak kayu. LPPK. 
Waryono, T 2004, Ekosistem rayap dan vektor demam berdarah di lingkungan permukiman. Seminar Sehari Penanggulangan Rayap dan Vektor Demam Berdarah pada Bangunan dan Perumahan, Klub Pesona Khayangan Estat, diakses pada tanggal 12 maret 2015, (https:// staff.blog.ui.ac.id).
Wulandini, R, Nurin, W, Fransiskus, H, Schmidt, Holger, L \& Dorthe, J 2004, Octomeles sumatrana Miq. Seed Lea $\square$ et No. 102. 